\title{
INGESTED LEAD SHOT IN SASKATCHEWAN DUCKS
}

\author{
by DAVID A. HARVEY*
}

The lead poisoning problem in aterfowl has inereased greatly sinee he early part of this eentury. In the Inited States, it has been estimated hat about $4 \%$ of the birds in the Mississippi Flyway fall vietim to this ickness each year.' No previous study as apparently been earried out in askatehewan on the lead poisoning roblem. A substitute for lead is being pught." 1 While lead shot is being hased out in the United States, it may e many years before it is banned in anada. Even after a ban, the tons of ad on the bottoms of potholes, lakes nd rivers will take many years to issolve or sink. Meanwhile, waterowl will eontinue to swallow spent hot, mistaking it for grit or seeds." lost shot takes about 40 days (depening on the size) to eompletely issolve onee in the gizzard of a bird. ${ }^{3}$ he number of shot a bird ean ingest efore serious effeets are noticeable aries with the health of the bird and s. diet. Oeeasionally, one pellet may Huse death.' Waterfowl affected by ad poisoning show signs of maciation and weakness. The fisoning also reduces the bird's bility to reproduee even when it does ot eause death. Dueks eontaining gested lead are usually safe for uman consumption due to the small nount of lead involved.

To obtain some information regaring the potential seriousness of the

Wadena, Saskatchewan. lead poisoning problem in southern Saskatehewan, a study was undertaken in seven areas. The samples used for analysis were 123 gizzards of ducks, shot between October 15 and Deeember 1, 1973. The gizzards were kept frozen until January 30, 1974 when they were $x$-rayed at the Kelsey Institute of Applied Arts and Seienees, Saskatoon with the assistanee of Mrs. M. Asher. Lead pellets showed in the $\mathrm{x}$-rays as whitish circles up to $3 \mathrm{~mm}$ in diameter (dark spots in Fig. 1). The number of pellets observed was reeorded and gizzards with pellets were kept frozen.

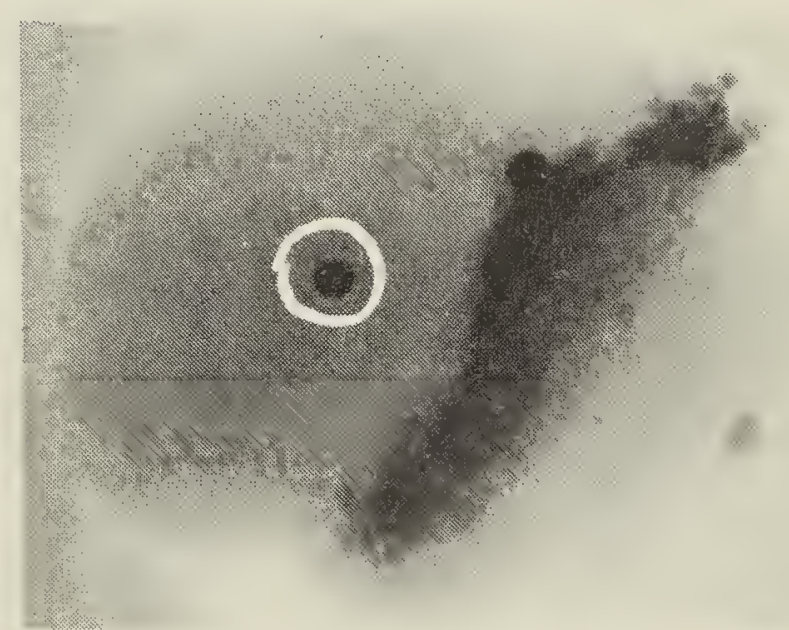

Figure 1 - X-ray of two pellets in a duck gizzard. Circled pellet was ingested, other was shot into the bird in killing it.

Beeause the ducks were eollected by shotgun, some pellets may have entered the gizzards when the duck was shot. To separate these, the gizzards were washed and examined earefully for punetures made by pellets. Such holes were easily loeated. Pellets whieh had been shot in eould then be 


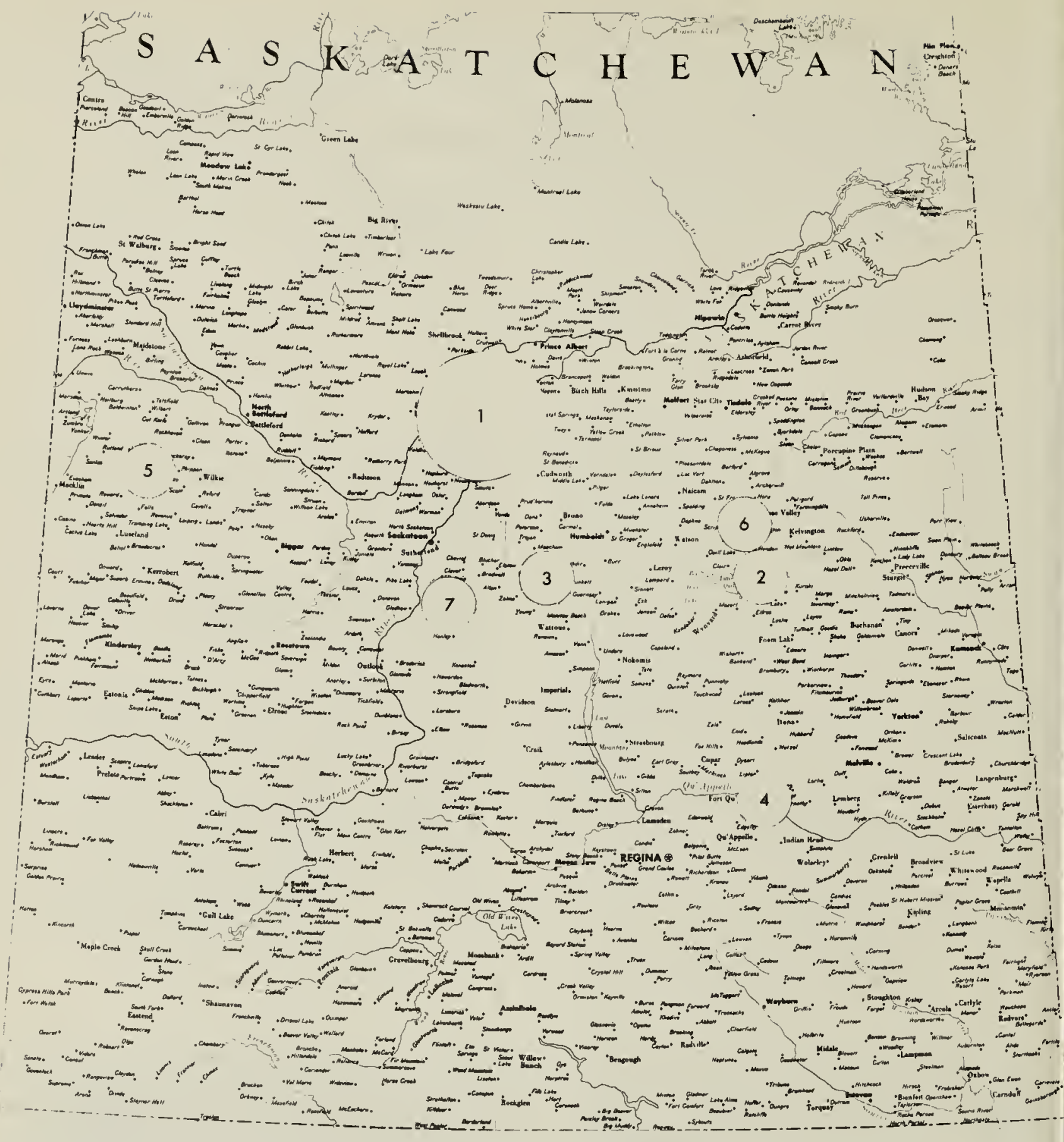

Fig. 2. Locations of ducks collected for ingested lead shot study: 1. Duck Lake (24-m radius); 2. Wadena (10-mile radius); 3. Viscount; 4. Fort Qu'Appelle; 5. Unity: Fosston; and 7. Dundurn.

found by dissecting the gizzard along the line of entry. Ingested pellets were often more difficult to locate because they were mixed with grit and partially digested vegetation and because ingested pellets were sometimes partially dissolved.

The seven collection areas are shown in Figure 2. Three gizzards were unidentified as to origin. Each area had a radius of 10 miles except for the Duck Lake area where the radius was 24 miles. The larger area was an amalgamation of two smal collection areas, each with sm sample sizes. The areas establisl. in the study are: (1) Duck La (2) Wadena, (3) Viscount, (4) F Qu'Appelle, (5) Unity, (6) Foss and (7) Dundurn. The 15 Duck L gizzards were collected from C worth, Hague and Tway. The 9 samples collected from the Foss $n$ area originated from Ponass Lake 5 miles west of Fosston) and Hend 1 . The 49 Dundurn gizzards came fr. $n$ Indi Lake. 
Table 1. Comparison of observed and ingested lead pellets in Saskatchewan ducks. (Observed/ingested in one gizzard.)

$\begin{array}{lccccc}\text { Areal } & \text { Mallard } & \text { Pintail } & \text { Wigeon } & \text { Total } & \\ \text { f. Fosston } & 1 / 0,2 / 1,1 / 1 & 1 / 1 & 1 / 1 & - & 6 / 4 \\ \text { 6. Hendon } & 1 / 0 & - & - & - & 1 / 0 \\ \text { 6. Ponass Lake } & 1 / 0,2 / 2,1 / 1,2 / 1 & - & - & - & 6 / 4 \\ \text { 7. Indi Lake } & 1 / 0,1 / 1,1 / 1 & - & - & 1 / 1 & 4 / 3 \\ & & & & & \\ \text { Areat } & \text { Mallard } & \text { Pintail } & \text { Wigeon } & \text { Canvilsback } & \text { Total } \\ \text { TOTAL } & 14 / 8 & 1 / 1 & 1 / 1 & 1 / 1 & 17 / 11 \\ \text { No. gizzards } & 11 & 1 & 1 & 1 & 14\end{array}$

The total number of gizzards was 123. Table 1 shows ingested lead pellets in the 10 ducks. Eleven pellets were observed in the 10 gizzards. Of these, 9 had been ingested in 9 gizzards. Only one gizzard (10\%) was found with two ingested pellets.

Ingested shot was found in gizzards from only two of the eight study areas. Of 39 gizzards from the Fosston area, seven contained ingested pellets $18 \%$ of that sample. Of 49 gizzards from Indi Lake, $3(6 \%)$ contained ingested pellets (Table 1). Eight percent of all gizzards had ingested shot.

The 106 Mallard gizzards made up $87 \%$ of the sample. There were four gizzards from Lesser Scaup, three from American Wigeon, two from Shovelers and one each from Pintail, Redhead, Canvasback, Gadwall and Blue-winged Teal. Of the ducks containing ingested shot, $70 \%$ were Mallards.

The information shows that the frequency of birds with ingested shot is higher in the more easterly study area. This may be due to heavier hunting pressure in the Fosston area. Another factor may be a difference in bottom types of the lakes. A soft bottom will allow spent shot to sink out of the reach of feeding ducks whereas pellets in wetlands with firm bottoms may take longer to sink.
Of 106 Mallards collected, $6.6 \%$ contained ingested lead. This is more significant than with the other species because of the large sample. One Wigeon out of three contained ingested shot and the only Canvasback and Pintail collected had ingested shot.

It is interesting to note that $8.1 \%$ of all ducks contained ingested lead. A similar survey done in the United States on a much larger scale showed that $6.7 \%$ contained ingested shot.' That study included 20 species of waterfowl of which Mallards were most susceptible to lead poisoning because of their food habits.'

One pellet was found in $90 \%$ of the infected gizzards. This is enough number 6 shot to kill up to $12 \%$ of adult male Mallards but less of other age and sex groups. Two number 6 shot caused $44 \%$ of mortality among adult male Mallards.'

The above results indicate that less than $1 \%$ of the duck population in Saskatchewan may die from ingested pellets. So, although lead poisoning is present in Saskatchewan ducks, it appears not to be a major cause of mortality. A similar study should be carried out in more heavily hunted areas of the province with a much larger sample size. These study areas should include Kindersley, Last 
Mountain Lake and the Quill Lakes. With hunting pressure constantly increasing and if lead shot continues to be used, the mortality of Saskatchewan ducks due to lead poisoning can only increase. Monitoring this mortality factor is inexpensive and should be initiated on a large scale. Further studies may aid in preventing this cause of waterfowl mortality from becoming more serious.

'BELLROSE, F. C., Jr. 1964. Spent shot and lead poisoning. Waterfowl Tomorrow. United States Gov't. Printing Office, Washington, 479-485.
¿FLANEGAN, GENE. 1970. Lead poisoni problem solved? Ducks Unlimited Quarter 33(1), Chicago, 16 p.

"KIMBALL, W. H., and Z. A. MUNIR. 19 The corrosion of lead shot in a simulated wat fowl gizzard, Jour. Wildl. Mgmt. 35: 360-36

4TENNYSON, JON. 1971. The quest for a solutic Ducks Unlimited Quarterly 34(2), Chicago, p.

TTRAINER, D. O., and R. A. HUNT. 1965. Le poisoning of waterfowl in Wisconsin, Jour. Wil Mgmt. 29: 95-103.

\title{
THE COMMON DANDELION
}

\author{
by MARIE BARTON*
}

"Oh, dandelion, yellow as gold, What do you do all day?"

So read my prescribed grade-three reader in my early years. My preschool granddaughter with the imagination of a poet shouts, "Oh, look at those dandelions sitting on the clothesline!" I look and see a row of eye-catching goldfinches, eaters of dandelion seeds. They eat the flowers, too. A color food?

Children still make chains from the hollow, milky stalks of these flowers that bloom from May to September. They tell fortunes by blowing the cluster of white-plumed, beaked seeds from their platform until all have

\footnotetext{
*42 Echo Bay,

Winnipge, Manitoba

R2J 2 A 3
}

taken to the air. When the disks of $t$ composite gleam with its packe golden ray florets, the wild bee gath the pollen for bee bread and the nect for honey.

"If only they bloomed at Chri mas," sighs my retired, Swedish neig bor in the suburbs. He loves these ' $l$ starts' in his lawn less than do t children, the goldfinches and the be But he has lived enough years remember back to the homestead da Then he helped his grandfather cal water from the well to a carefu fenced, cultivated patch of the precious vegetables that he calls in mother tongue by the name of dev ; milk pots. (The French say dent-i. lion, meaning lion's tooth - 